\title{
KONSEP KOMARUDDIN HIDAYAT TENTANG TERAPI KETAKUTAN TERHADAP KEMATIAN
}

\author{
Mega Herdina \\ Alumni Jurusan Psikologi Islam \\ Fakultas Ushuluddin dan Humaniora IAIN Antasari Banjarmasin
}

\begin{abstract}
It is normal that human beings fear death, even though everybody knows that, one day, he or she will die. Death is scary because one does not know wat will happen after death. A person who feels happy in this life will also fear death because he/she will leave the happy life. Komaruddin Hidayat, in his popular book, Psikologi Kematian, tries to discuss this problem. He suggests that in order to face death calmly, one has to know what death is, and what will happen to him/her in the life after death. He also maintains that, abstention from worldly pleasures may help one to be ready to face death. Above all, for him, the most important thing to do is to find the meaning of life.
\end{abstract}

Kata kunci: psikologi kematian, terapi ketakutan, pencarian makna

\section{Pendahuluan}

Kematian merupakan hal yang niscaya dan tidak bisa dihindari dalam kehidupan manusia. Eksistensi manusia bersifat nyata, konkrit, dan absolut tapi kematian juga nyata dan tidak terelakkan. Kematian adalah salah satu dari perjalanan hidup manusia sebagai makhluk yang diciptakan Allah Swt. Menurut Islam, kematian merupakan terlepasnya roh dari tubuh manusia dan tidak kembali lagi. ${ }^{1}$

Ketika seseorang membicarakan kematian maka akan timbul suatu pemberontakan dalam dirinya, serta kepedihan dan ketakutan. Hal ini disebabkan anggapan mereka bahwa mati adalah akhir dari segala kesenangan dan kenikmatan yang dirasakannya di dunia. ${ }^{2}$ Jika dilihat secara psikologis, sesungguhnya setiap manusia itu menolak kematian. Sakit dan celaka adalah jembatan menuju kematian oleh karena itulah setiap orang akan dibayangi rasa takut pada situasi yang tidak nyaman, semua orang akan berusaha menghindari jalan kearah gerbang kematian. ${ }^{3}$ Terlebih lagi manusia yang menjalani usia lanjut, karena manusia usia lanjut merupakan manusia yang sudah tidak produktif lagi. Kondisi fisik yang menurun dan berbagai penyakit yang diderita pasti dialami oleh setiap manusia usia lanjut. Sehingga, kadang timbul pikiran bahwa sekarang mereka pada sisa-sisa umur menunggu kematian. ${ }^{4}$

\footnotetext{
${ }^{1}$ Aliah B. Purwakania Hasan, Psikologi Perkembangan Islami: Menyingkap Rentang Kehidupan Manusia dari Prakelabiran Hingga Pascakematian, cet. 2, (Jakarta: Rajawali Pers, 2008), h. 324.

${ }^{2}$ Komaruddin Hidayat, Psikologi Kematian: Mengubah Ketakutan menjadi Optimisme, cet. 15, (Jakarta: Hikmah, 2010), h. xvi.

${ }^{3}$ Komaruddin Hidayat, Psikologi Kematian., h. xviii.

${ }^{4} J a l a l u d d i n$, Psikologi Agama: Memahami Perilaku Keagamaan dengan Mengaplikasikan Prinsip-prinsip Psikologi, (Jakarta: Rajawali Pers, 2010), cet. 3, h. 112.
} 
Di Indonesia ada beberapa ilmuwan muslim yang mencoba menulis buku tentang kematian untuk membantu memberikan pemahaman positif terhadap kematian ini. Salah satunya Komaruddin Hidayat dengan buku-bukunya seperti Berdamai dengan Kematian: Menjemput ajal dengan optimisme (2009) dan buku Psikologi Kematian: Mengubah ketakutan menjadi optimisme (2007) yang juga merupakan karya Komaruddin Hidayat, dan lain-lain. Yang menjadi permasalahan sekarang adalah bagaimana psikologi kematian dalam pandangan Komaruddin Hidayat dan bagaimana terapi yang ditawarkan Komaruddin Hidayat untuk menghadapi perasaan takut terhadap kematian tersebut.

\section{Manusia dan Kematian}

Al-Qur'an menyebutkan bahwa manusia diciptakan dari tanah dan setelah disempurnakan kejadiannya dihembuskan kepadanya Ruh Ilahi, sebagaimana proses penciptaan manusia pertama yaitu Adam. Sesuai surah Shad ayat 71-72, sebagaimana berikut ini:

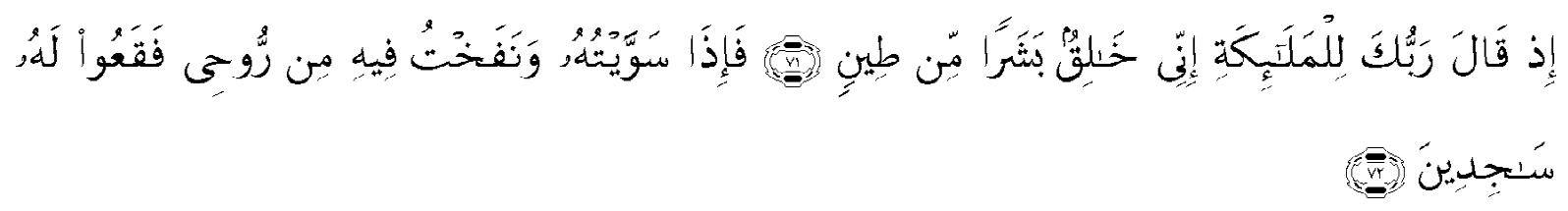

Abdul Mujib dalam bukunya Kepribadian dalam Psikologi Islam menyebutkan ada 3 elemen yang ada dalam diri manusia, yaitu jasad, ruh, dan nafs. ${ }^{5} \mathrm{Jasad}$ merupakan aspek biologis atau fisik manusia, ruh merupakan aspek psikologis atau psikis manusia, sedang nafs merupakan aspek psikofisik manusia yang merupakan sinergi antara jasad dan ruh. Adapun kriteria-kriteria ketiganya dijelaskannya seperti kutipan dibawah ini:

...Jasad sifatnya kasar dan indrawi atau empiris, naturnya buruk, asalnya dari tanah bumi (ardhiyyah), dan kecendrungannya ingin mengejar kenikmatan duniawi atau material. Sedangkan ruh sifatnya halus dan ghaib, naturnya baik, asalnya dari hembusan langsung dari Allah (ilabiyyah) dan kecenderungannya mengejar kenikmatan samawi, ruhaniah dan ukhrawiah. Masing-masing dimensi yang berlawanan naturnya ini pada prinsipnya saling membutuhkan. Jasad tanpa ruh merupakan substansi yang mati, sedang ruh tanpa jasad tidak dapat teraktualisasi. Oleh sebab itu, perlu adanya sinergi antara kedua aspek yang berlawanan ini, sehingga menjadi nafs. Dengan nafs maka masing-masing keinginan jasad dan ruh dalam diri manusia dapat terpenuhi. ${ }^{6}$

Setiap makhluk yang hidup pasti akan mengalami kehancuran. Kematian adalah satu kehancuran manusia dimulai dengan hancurnya sistem pada tubuh. Mendefinisikan kematian sama sulitnya dengan mendefinisikan kehidupan, ini dikarenakan kematian didefinisikan secara berbeda, beberapa tokoh juga membahas mengenai kematian namun dari sudut pandang yang berbeda-beda. Ada yang mengulas dari sisi fisika, ada pula yang mengulas dari fenomena biologi, dari fenomena kemasyarakatan dan sisi yang lainnya.

\footnotetext{
${ }^{5}$ Abdul Mujib, Kepribadian dalam Psikologi Islam, cet. 2, (Jakarta: RajaGrafindo Persada, 2007), h. 56. ${ }^{6}$ Abdul Mujib, Kepribadian dalam Psikologi Islam, h. 56-57.

${ }^{7}$ Muhammad Damm, Kematian: Sebuah Risalah Tentang Eksistensi dan Ketiadaan, cet. 1, (Depok: Kepik, 2011), h. 41.
} 
Secara definisi umum, kematian adalah berakhirnya proses kehidupan (vital process), demikian menurut Steven Luper yang dikutip Muhammad Damm. ${ }^{7}$ Kematian juga didefinisikan sebagai kehilangan permanen dari fungsi integratif manusia secara keseluruhan. Secara medis, kriteria kematian apabila nafas dan jantung sudah tidak berfungsi, seluruh sel dalam tubuh juga akan mengalami kematiannya. Pasokan oksigen dan zat-zat gizi semuanya bakal berhenti dan tidak lagi menghidupi sel. Maka tidak lama kemudian miliaran sel di tubuh akan mengalami kehancuran secara dramatis dan kemudian membusuk. ${ }^{8}$ M. Quraish Shihab dalam bukunya Wawasan AlQur'an menyebutkan bahwa para ulama mendefinisikan kematian sebagai "ketiadaan hidup", atau "antonim dari bidup."

Al-Syinqithi membagi konsep kematian dengan dua kategori, yaitu:

1. Mati dikarenakan lepasnya ruh secara terus menerus dan habisnya daya hidup pada tubuh manusia. Kematian model ini disebabkan hilangnya daya-daya inderawi manusia;

2. Mati dikarenakan lepasnya ruh pada diri manusia dalam waktu sementara, sehingga jasad manusia tidak ber-nafs lagi. Hal ini digambarkan seperti orang yang sedang tertidur, yang mana ruh manusia mampu melayang kemana saja yang ia sukai dan ruh akan kembali kepada jasad pada saat ia terjaga. ${ }^{10}$

Jika ditelusuri setiap manusia pasti memiliki rasa takut terhadap kematian dan ada anggapan bahwa orang yang mati seperti mengalami sebuah penderitaan yang tak terbebankan. Dengan kematian, kehidupan dunia seseorang menjadi terputus dan akan ada duka mendalam dikutip dalam skripsi Siti Aminah, bahwa orang yang takut mati karena tidak tahu kemana jiwanya akan pergi karena ia berasumsi bahwa kalau tubuhnya sudah hancur maka akan hancur pula jiwanya. ${ }^{11}$ Makanya tidak mengherankan seseorang akan mengalami stres ketika divonis oleh Dokter terkena kanker Stadium IV, stres ini disebabkan karena kesimpulan yang ada bahwa kanker berarti mendekati kematian. Rasa takut kematian yang dimiliki setiap manusia berbeda kadar dan sifatnya saja, entah itu bersifat konstruktif ataupun deskruktif tergantung bagaimana ia mengolah rasa takut tersebut.

Sebenarnya akal dan perasaan manusia pada umumnya enggan menjadikan kehidupan atau eksistensi mereka terbatas pada puluhan tahun saja. Walaupun manusia menyadari bahwa mereka harus mati, namun pada umumnya manusia menilai kematian berarti kepunahan. Keengganan manusia menilai kematian sebagai kepunahan tercermin, antara lain melalui penciptaan berbagai cara untuk menunjukkan eksistensinya. Misalnya, dengan menyediakan kuburan, atau tempattempat tersebut dikunjunginya dari saat ke saat sebagai manifestasi dari keyakinannya bahwa yang telah meninggalkan dunia itu tetap masih hidup walaupun jasad mereka telah tiada. ${ }^{12}$

Ada banyak faktor yang membuat seseorang enggan untuk mati. Ada yang beranggapan bahwa yang dimilikinya sekarang ini lebih baik daripada yang akan didapatkannya nanti, atau

\footnotetext{
${ }^{8}$ Agus Mustofa, Menyelam ke Samudera Jiwa dan Ruh, (Surabaya: Padma Press, 2005), h. 222.

${ }^{9}$ M. Quraish Shihab, Wawasan al-Qur'an: Tafsir Maudhu'i atas Pelbagai Persoalan Umat, cet. 6, (Bandung: Mizan, 1997), h. 68.

${ }^{10}$ Abdul Mujib, Kepribadian dalam Psikologi Islam, h. 64.

${ }^{11}$ Siti Aminah, Konsep Kematian Menurut Mufassir: Studi tentang Persiapan dan Tempat Roh setelah Pisah dengan Badan, (Skripsi tidak diterbitkan, Fakultas Ushuluddin, IAIN Antasari, Banjarmasin, 1997), h. 68-69.

${ }^{12}$ M. Quraish Shihab, Wawasan al-Qur'an, h. 70.

${ }^{13}$ M. Quraish Shihab, Wawasan al-Qur'an, h. 69.
} 
bisa juga dikarena ia membayangkan betapa pedihnya ketika mengalami kematian, bisa dikarenakan perasaan kahawatir terhadap keluarga yang ditinggalkannya dan lain sebagainya. ${ }^{13}$ Pandangan mengenai kematian bagi beberapa kalangan memang merupakan sesuatu penderitaan apalagi jika hanya mendengar majelis-majelis ta'lim yang hanya menjelaskan tentang kematian dari segi penderitaannya saja seperti pencabutan nyawa yang rasanya seperti dikuliti hidup-hidup dan berbagai cerita menakutkan tentang proses kematian, namun jika ditelaah secara lebih dalam sebenarnya banyak hal yang menyenangkan dan indah tentang kematian. Pandangan yang negatif terhadap kematian pada akhirnya melahirkan pandangan-pandangan optimis dan pesimistis terhadap kematian dan kehidupan.

Manusia menyaksikan bagaimana kematian tidak memilih usia atau tempat, tidak pula menangguhkan kehadirannya sampai terpenuhi semua keinginan. Di kalangan sementara orang, kematian menimbulkan kecemasan, apalagi bagi mereka yang memandang bahwa hidup hanya sekali yakni di dunia ini saja. Sehingga tidak sedikit yang pada akhirnya menilai kehidupan ini sebagai siksaan, dan untuk menghindar dari siksaan itu, mereka menganjurkan agar melupakan kematian dan menghindari sedapat mungkin segala kecemasan yang ditimbulkannya dengan jalan melakukan apa saja secara bebas tanpa kendali, demi mewujudkan eksistensi manusia. ${ }^{14}$

Ibnu Miskawaih menganalisis sebab-sebab ketakutan manusia terhadap kematian, dan ia menyebutkan sebab-sebab itu sebagai berikut:

1. Tidak mengetahui hakikat dari kematian.

2. Tidak mengetahui nasib jiwa setelah kematian.

3. Dugaan bahwa jika badan rusak dan susunannya hancur maka zatnya akan hancur dan jiwanya akan rusak, serta dugaan bahwa alam akan selalu abadi, sedangkan ia tidak berada di dalamnya.

4. Dugaan bahwa kematian adalah penderitaan besar yang berbeda dengan penderitaan sebelumnya dan yang menimbulkan kematian.

5. Kepercayaan bahwa ia akan mendapatkan siksaan setelah kematian.

6. Kebingungan dan ketidaktahuan atas apa yang akan ia berikan setelah kematian.

7. Menyesali uang dan simpanan yang ia tinggalkan. Ini biasanya dikarenakan seseorang terlalu mencintai apa yang ia miliki tanpa menyadari semua itu hanyalah titipan semata. ${ }^{15}$

\section{Psikologi Kematian dalam Perspektif Komaruddin Hidayat}

Menurut yang diungkapkan Komaruddin Hidayat dalam pengantarnya pada buku Spiritualitas Kematian, jika dilihat secara lahiriah kematian adalah bencana yang memutus dan mengakhiri kehidupan. Tidak tahu apa yang akan terjadi setelahnya kecuali jasad kita dimasukkan dalam tanah kemudian ditutup dengan tanah. ${ }^{16}$ Keadaan semacam ini tentu saja sangat menakutkan dan semua orang enggan mengalaminya.

\footnotetext{
${ }^{14}$ Muhammad Utsman Najati, Jiwa dalam Pandangan Para Filosof Muslim, terj. Gazi Saloom, cet. 1, (Bandung: Pustaka Hidayah, 2002), h. 107-108.

${ }^{15}$ Muhammad Utsman Najati, Jiwa dalam Pandangan Para Filosof Muslim, h. 69-70.

${ }^{16}$ Komaruddin Hidayat, Pengantar. Lihat, Abdul Mustaqim, Spiritualitas Kematian: Meraih Hidup Indah dan Khusnul Khatimah, cet. 1. (Yogyakarta: Kaukaba, 2011),
} 
Mengapa sebagian orang takut akan kematian ? Tidak jauh berbeda dengan pendapat tokoh lain seperti yang disebutkan di atas, Komaruddin Hidayat menjelaskan adanya beberapa alasan kenapa kematian begitu menakutkan. Pertama, sebagian orang merasa dimanjakan oleh dunia. Kedua, manusia tidak mengetahui apa yang akan terjadi setelah mati. Ketiga, seseorang merasa banyak dosanya. Ketiga alasan ini dipaparkan Komaruddin Hidayat dalam bukunya Psikologi Kematian,

Mengapa kematian begitu menakutkan sedangkan dunia sangat sayang untuk ditinggalkan? Terdapat beberapa kemungkinan jawaban muncul. Antara lain ialah, bagi sebagian orang yang merasa dimanjakan oleh kenikmatan yang telah dipeluknya selama ini. Dengan demikian memasuki hari tua berarti memasuki fase penyesalan, sedangkan kematian adalah puncak kekalahan dan penderitaan. Jawaban lain, kematian ditakuti karena manusia tidak tahu apa yang akan terjadi setelah mati. Kalau saja seseorang bisa menghilangkan benih iman dan argumen filosofi akan adanya keabadian jiwa, sangat bisa jadi orang tak akan takut mati. Bukankah setelah kematian tidak akan ada kehidupan lagi? Tetapi persoalannya, manusia sulit untuk mengingkari kebenaran ajaran agama, rasa keadilan moral dan argumen filosofis bahwa keabadian jiwa dan hari perhitungan itu pasti terjadi... jawaban lainnya ialah, orang takut mati karena seseorang merasa banyak dosanya, lebih banyak amal kejahatannya ketimbang kebaikannya, sehingga takut akan imbalan siksa yang hendak diterimanya kelak. ${ }^{17}$

Komaruddin Hidayat juga menyebutkan dalam bukunya tentang ketidakinginan manusia meninggalkan apa yang dimiliki di dunia,

... Secara psikologis, jika ditelusuri lebih dalam lagi karena sesungguhnya kita semua menolak kematian. Sakit dan celaka adalah jembatan ke arah kematian sehingga setiap orang selalu dibayangi rasa takut terhadap semua situasi yang tidak nyaman. Rasa takut itu berakar pada keinginan laten untuk selalu hidup nyaman, dan rasa takut itu kemudian menjalar kepada berbagai wilayah aktivitas manusia. Lebih jauh lagi, rasa takut itu kemudian melahirkan anak-pinak, yaitu takut akan bayang-bayang ketakutan itu sendiri, sehingga muncul ungkapan, musuh besar dan terdekat kita adalah rasa takut itu sendiri yang berakar kuat dalam diri. Essensinya ialah sikap penolakan akan kematian karena kematian selalu diidentikkan dengan tragedi, sakit, ketidakberdayaan, kehilangan dan kebangkrutan hidup. ${ }^{18}$

Sebenarnya kematian tidaklah harus ditakuti secara deskruktif, ketakutan timbul dikarenakan banyak informasi yang masih belum diketahui tentang kematian. Hendaklah rasa takut tersebut dijadikan bahan pacuan untuk memberikan semangat bagi diri agar lebih giat lagi dalam menaati perintah Allah swt.

Komaruddin Hidayat menganalogikan kematian sebagai peristiwa pulang kampung bagi ruh. Seseorang yang telah lama berada di negeri orang tentu akan sangat bahagia apabila kembali ke kampung halaman sendiri, begitu pula dengan kematian dunia merupakan tempat persinggahan kapal kehidupan yang sifatnya sementara waktu, dan setiap orang memiliki tugas untuk mengumpulkan bekal sebanyak-banyaknya untuk bekal yang bisa dibawa pulang ke

\footnotetext{
${ }^{17}$ Komaruddin Hidayat, Psikologi kematian, h. 118-120.

${ }^{18}$ Komaruddin Hidayat, Psikologi kematian (Pengantar Wacana), h. xx.
} 
kampung halaman nanti. Bagi mereka yang fokus dengan tujuan, mereka akan melakukan dengan segala daya untuk mengumpulkan bekal sehingga membuat bangga karena berhasil membawa bekal yang banyak sedangkan mereka yang terlena oleh indahnya tempat persinggahan akan hanyut dan lupa untuk mencari bekal, dan ketika terompet kapal berbunyi barulah tergopoh-gopoh dan bingung mencari bekal untuk pulang, namun terlambat karena kapal tetap harus berangkat menuju tujuan. ${ }^{19}$

Sebenarnya ruh pada saat berada dalam tubuh merasa terkurung dan terbelenggu dan dengan kematianlah ia mampu bebas, seperti yang disebutkan oleh Komaruddin Hidayat:

"Dalam literatur sufi sering dituturkan kembali bahwa jiwa manusia yang bersifat ruhani bagaikan sang rajawali yang terkurung dalam sangkar tubuh. Ruh manusia berasal dari Allah dengan misi agung mengendalikan semua instrumen tubuh, akal dan emosi untuk melaksanakan kekhalifahan Allah di muka bumi..." ${ }^{20}$

Dengan keluarnya ruh dari badan, itu berarti bahwa kebebasan telah diperoleh sang ruh. Berasal dari Allah swt dan dengan kematian ia bisa kembali ke sisi Allah swt.

Komaruddin Hidayat mengatakan bahwa kematian merupakan wisuda kehidupan, oleh karena itu setiap orang pasti berharap bisa lulus dengan nilai yang baik atau kalau bisa mendapat nilai cumlaude. Untuk mendapatkan nilai cumlaude ini seseorang harus sungguh-sungguh belajar dalam perkuliahan, berusaha untuk selalu melakukan yang terbaik agar mendapatkan nilai yang baik. Begitu pula dengan kehidupan ini, seseorang harusnya lebih ektra dalam beribadah dan menaati perintah Allah swt. Agar nantinya mendapatkan bekal yang baik pada saat kematian menjemput. $^{21}$

Dengan kematian yang pasti terjadi, maka tinggal bagaimana kita menanggapi hal tersebut apakah mempergunakan waktu yang tersisa dengan memperbanyak amal sholeh serta kebaikan terhadap sesama. Kelak jika kita meninggal masih banyak kenangan yang diingat oleh orang lain disamping kitapun memiliki bekal yang cukup untuk dibawa pulang ke kampung akhirat. ${ }^{22}$ Oleh karena itulah, mengingat kematian bukanlah sesuatu yang salah, malah dianjurkan oleh agama. Dengan mengingat kematian seseorang diharapkan mampu untuk memperbaiki diri dan memperbanyak amal shaleh.

\section{Terapi Ketakutan Terhadap kematian}

Setiap rasa takut memiliki dua sifat yaitu takut yang bersifat konstruktif yaitu rasa takut yang berdampak positif dan memberikan keoptimisan bagi orang tersebut. Rasa takut yang konstruktif mampu membuahkan hal-hal yang baik dan positif, memberikan motivasi untuk bisa melakukan yang lebih baik daripada keadaan sebelumnya. Lain halnya dengan rasa takut yang bersifat destruktif, bukannya membuahkan hal positif namun rasa takut yang seperti ini membuat seseorang menjadi pesimis, dampak negatif yang dihasilkan akan sangat mengganggu jalannya kehidupan, rasa takut yang destruktif akan membuahkan sesuatu yang lebih buruk dari keadaan sebelumnya.

\footnotetext{
${ }^{19}$ Komaruddin Hidayat, 250 Wisdoms: Membuka Mata, Menangkap Makna, cet. 1, (Jakarta: Mizan, 2010), h. $264-265$.

${ }^{20}$ Komaruddin Hidayat, Psikologi Kematian, h. 55.

${ }^{21}$ Komaruddin Hidayat, 250 Wisdoms, h, 268-269.

${ }^{22}$ Komaruddin Hidayat, 250 Wisdoms, h. 264.
} 
Ketika seseorang telah mengalami ketakutan yang destruktif maka ia perlu terapi untuk mengubah rasa takut yang destruktif tersebut menjadi ketakutan yang konstruktif. Seperti halnya ketakutan terhadap kematian, setiap manusia akan berbeda dalam menghadapi rasa takutnya. Ada sekelompok orang yang semakin baik diriya saat takut mati, akan tetapi ada pula orang yang malah pesimis dan tidak semangat untuk hidup. Orang yang pesimis inilah yang disebut memiliki ketakutan destruktif. Salah satu terapi yang ditawarkan sebagai alternatif adalah konsep Komaruddin Hidayat, melalui beberapa bukunya ia banyak memaparkan berbagai jalan untuk membangun perasaaan takut terhadap kematian yang konstruktif.

Jika dianalisa dalam bukunya Psikologi Kematian, Komaruddin Hidayat memberikan beberapa terapi untuk mengubah ketakutan yang destruktif terhadap kematian menjadi ketakutan yang konstruktif, dalam artian ketakutan tersebut mampu mengubah prilaku menjadi lebih baik lagi. Penulis menemukan setidaknya ada 4 cara yang dapat ditempuh untuk mengubah rasa takut menjadi opitimis terhadap kematian. Pertama mendekatkan diri kepada Allah, kedua menambah wawasan tentang kematian, ketiga melepaskan diri dari kepemilikan duniawi, dan keempat dengan cara pencarian makna.

\section{Mendekatkan diri kepada Allah}

Cara pertama untuk mengubah rasa takut yang destruktif adalah mendekatkan diri kepada Allah, dengan cara ini mampu memberikan ketenangan pada seseorang. Mendekatkan diri kepada Allah juga bermakna memperbanyak ibadah dan kebaikan yang dilakukan.

Mendekatkan diri kepada Allah juga bisa ditempuh melalui ilmu tasawuf. Ilmu tasawuf memiliki inti yang terletak pada wilayah bathin atau berada pada dimensi spiritualitas. Lalu bagaimana paham tasawuf dalam mendekati Tuhan? Komaruddin Hidayat menjelaskan,

"Mereka lebih senang menatap Tuhan sebagai yang maha kasih. Cinta merupakan tema dan jalan pendekatan pada Tuhan yang paling disenangi oleh para sufi. Banyak puisi-puisi cinta yang menggelorakan cintanya pada Tuhan..."23

Untuk mampu mendekati Allah, maka langkah pertama yang harus kita ambil adalah mencintai Allah yang maha indah. Dengan kecintaan inilah timbul keinginan untuk selalu dekat dan menaati perintahnya.

Di dalam ilmu tasawuf diajarkan untuk memperbanyak shalat dan zikir, ini merupakan salah satu cara yang ditempuh seorang mukmin untuk mendekatkan diri pada Tuhannya. Dalam ritual shalat, do'a-do'a yang diucapkan dijadikan sebagai bentuk komunikasi dengan Tuhan. Bacaan shalat merupakan do'a-do'a yang menyimbolkan bahwa manusia itu kecil dan lemah sehingga ia memerlukan kekuatan yang lebih besar sebagai tempat berlindung. Sedangkan zikir dilakukan agar menambah keyakinan terhadap Tuhan dengan cara menyebut nama Tuhan secara berulang-ulang. Dengan dua cara inilah, diantaranya seseorang dapat mendekatkan diri kepada Tuhan, mencintainya dan memperbanyak ibadah kepadanya.

\section{Menambah wawasan tentang kematian}

Pada pembahasan sebelumnya telah dijelaskan adanya beberapa alasan seseorang takut akan kematian, salah satunya adalah mereka belum atau tidak tahu apa yang akan terjadi setelah

${ }^{23}$ Komaruddin Hidayat, Psikologi Kematian, h. 66. 
datangnya kematian. ${ }^{24}$ Namun hal itu bisa dimaklumi, karena informasi yang didengar memang sering menjelaskan kematian hanya dari sisi yang menyakitkannya saja, tidak dijelaskan definisi kematian dari sisi yang menyenangkan.

Dengan mengetahui secara spesifik mengenai kematian, diharapkan seseorang bisa memahami bahwa kematian bukanlah sesuatu yang harus ditakuti, karena mau atau tidak mau ia merupakan sesuatu yang tak terelakkan dan pasti. Bahkan jika kita mau menengok, bagi kaum sufi kematian merupakan sesuatu yang dinanti-nantikan karena kematian merupakan jalan untuk bisa bertemu Tuhan.

\section{Mampu melepaskan diri dari kepemilikan duniawi.}

Dari sudut pandang agama semua yang kita miliki hanyalah berfungsi sebagai fasilitas instrumental untuk sesuatu yang lebih maknawi. Dalam terminologi agama, yaitu kualitas iman yang kemudian teraktualisasikan ke dalam amal shaleh. Jadi ketika kita memiliki semua fasilitas instrumental, sejak dari harta, jabatan dan bahkan ilmu, kalau tidak membuahkan amal kebajikan bagi sesama manusia sebagai aktualisasi rasa syukur dan pengabdian pada Tuhan, maka sesungguhnya kita telah tertipu oleh pandangan hidup yang berskala pendek atau duniawi. ${ }^{25}$ Dengan melepaskan diri dari jeratan tali dunia, maka seseorang akan lebih enteng dalam menjalani hidup. Kematian yang menghadang pun akan santai saja menghadapinya karena tidak adanya yang membelenggu diri.

\section{Pencarian makna}

Pemaknaan hidup seseorang erat kaitannya dengan penghayatan agama yang ia miliki. Semakin dalam penghayatan tersebut, maka semakin dalam pula penghayatannya. Komaruddin Hidayat menegaskan bahwa hidup menjadi bermakna selama kita beri makna, namun hanya sebatas kehidupan dunia ini. ${ }^{26}$ Kebanyakan masalah masyarakat modern muncul, salah satu penyebabnya adalah keringnya makna dalam kehidupan.

Dalam pandangan hedonisme, hidup dikatakan bermakna selama memberikan kenyamanan dan kenikmatan. Pandangan kaum hedonis ini hanya memberikan harga dan makna hidup sebatas pada capaian nikmat fisik yang jelas tidak sejalan dengan ajaran agama. Berdekatan dengan pandangan hedonisme adalah paham nihilisme yang menyatakan bahwa manusia tak ubahnya seperti hewan ataupun benda lain yang kesemuanya berakhir ketika seorang meninggal. ${ }^{27}$

Dengan memaknai kehidupan, seseorang akan merasa enteng dalam menjalani kehidupan. Selain itu semangat hidup juga akan bertambah karena merasa bahwa hidupnya benar-benar bernilai. Ada beberapa hal yang perlu dimaknai untuk memberikan terapi terhadap ketakutan akan kematian dalam perspektif Komaruddin Hidayat diantaranya:

a. Memaknai kelahiran

Kelahiran ke dunia bukanlah sebuah kebetulan saja. Setiap manusia yang lahir ke dunia dengan membawa amanah dari Allah untuk menjadi khalifah-Nya di muka bumi ini.

\footnotetext{
${ }^{24}$ Lihat, Komaruddin Hidayat, Psikologi Kematian, h. 118-120.

${ }^{25}$ Komaruddin Hidayat, Psikologi Kematian, h. 125.

${ }^{26}$ Komaruddin Hidayat, Psikologi Kematian, h. 74.

${ }^{27}$ Komaruddin Hidayat, Psikologi Kematian, h. 74.
} 
Perjalanan hidup manusia ditujukan agar manusia memperbanyak ibadah sebagai bekal untuk kehidupan selanjutnya setelah kita tertidur panjang suatu saat nanti.

b. Memaknai kepemilikan

Kepemilikan itu memiliki hirarki, memiliki tingkatan-tingkatan makna. Tidak ada kepemilikan abadi karena pemilik sejati hanyalah Allah swt., manusia hanya dipinjamkan sesaat yang suatu saat akan diambil pemilik sejati. Komaruddin Hidayat mengumpamakan umumnya manusia seperti anak kecil yang dipinjami mainan, ketika mainannya diambil ia akan menangis karena menyangka mainan itu miliknya. ${ }^{28}$

Dari sudut pandang agama, Komaruddin Hidayat menjelaskan bahwa semua yang kita miliki hanyalah berfungsi sebagai fasilitas instrumental untuk sesuatu yang lebih maknawi. Dalam terminologi agama, yaitu kualitas iman yang kemudian teraktualisasikan ke dalam amal shaleh. Jadi, ketika diberikan amanah dalam bentuk harta, jabatan, bahkan ilmu sekalipun hendaknya amanah ini mampu memunculkan atau membuahkan kebajikan. ${ }^{29}$

c. Memaknai panjang umur

Umur memiliki makna positif yang bertalian dengan tingkat produktivitas seseorang. Orang yang berumur panjang artinya yang berhasil meraih kemakmuran hidup. Idealnya adalah kemakmuran dalam hal harta, ilmu dan amal. Jadi, sekalipun orang dikatakan memiliki umur panjang tetapi kalau hidupnya tidak produktif sama halnya dengan umur pendek atau bahkan mengalami kebangkrutan dalam umurnya karena fasilitas usia yang dimiliki tidak digunakan secara efisien dan produktif. ${ }^{30}$ Karena konsep panjang umur berkaitan dengan produktivitas maka seorang manusia tidak saja dituntut untuk melakukan kerja keras, namun juga bekerja secara efektif dan cerdas. Untuk meraih itu mutlak diperlukan badan sehat, ilmu pengetahuan dan keterampilan. ${ }^{31}$

d. Memaknai keabadian

Kehidupan abadi merupakan sesuatu yang pasti terjadi dan untuk menujunya seseorang harus mengalami kematian. Ketika keabadian dimaknai secara filosofis kemudian dikaitkan dengan kehidupan di dunia, maka keabadian bisa masuk ke dalam momentum yang tidak terikat oleh ruang dan waktu, melainkan merasa menyatu dengan yang absolut, disitulah kesadaran mulai terbuka untuk memahami dan menghayati makna keabadian. Dengan begitu, keabadian berkaitan dengan kekhusyuan dalam menjalani setiap pekerjaan, sampai seseorang memasuki zona Tuhan yang maha Abadi. ${ }^{32}$

e. Memaknai kematian

Kematian adalah pintu gerbang untuk memasuki kehidupan baru yang lebih indah, sebuah kebahagiaan yang sejati. Ibarat anak sekolah, lewat kematian sesungguhnya arwah dari orang-orang yang hidupnya penuh kesalehan akan dinaikkan kelasnya. ${ }^{33}$ 96.

${ }^{28}$ Komaruddin Hidayat, Berdamai dengan Kematian : Menjemput ajal dengan optimisme, cet. 2, (Jakarta: Mizan, 2009), h. $95-$

\footnotetext{
${ }^{29}$ Komaruddin Hidayat, Psikologi Kematian, h. 125.

${ }^{30}$ Komaruddin Hidayat, Psikologi Kematian, h. 90.

${ }^{31}$ Komaruddin Hidayat, Psikologi Kematian, h 91.

${ }^{32}$ Komaruddin Hidayat, Psikologi Kematian, h . 99.

${ }^{33}$ Komaruddin Hidayat, Psikologi Kematian, h. 115.
} 
Merenungkan makna kematian tidak berarti lalu kita pasif. Sebaliknya, justru lebih serius menjalani hidup, mengingat fasilitas umur yang teramat pendek. Ibarat orang lomba lari, maka ia akan berpacu karena adanya batas waktu dan garis finis. Barangkali saja banyak orang merasa dirinya sukses dan berjaya dalam memenangkan hidup, ketika mereka berhasil memperdayakan hukum, merampok uang rakyat dan negara dengan berbagai kedok dan kekuasaan politik, padahal yang sesungguhnya terjadi mereka tanpa sadar tengah memperdalam liang kenistaan bagi dirinya sendiri. ${ }^{34}$

Seperti yang disebutkan pada pembahasan yang lalu bahwa Komaruddin Hidayat menyebutkan ada beberapa alasan mengapa seseorang takut terhadap kematian. Untuk mengubah rasa takut tersebut Komaruddin Hidayat memberikan terapi berupa pemahamanpemahaman yang benar mengenai kematian, oleh karena itulah penulis berkesimpulan bahwa terapi yang diberikan oleh Komaruddin Hidayat ini adalah rational-emotive-behavior therapy. Hal ini terbukti dengan penjelasan-penjelasan Komaruddin Hidayat untuk mengubah rasa takut yang pesimis kepada rasa takut yang optimis dengan cara mengubah pemahaman atau rasio yang berhubungan dengan kognitif orang yang memiliki rasa takut tersebut.

Rational-emotive-behavior therapy adalah salah satu terapi dalam ilmu psikologi yang dikembangkan oleh Albert Ellis. Terapi ini mementingkan berpikir rasional sebagai tujuan terapiutik, menekankan modifikasi atau pengubahan keyakinan irrasional yang merusak berbagai konsekuensi emosional dan tingkah laku atau ringkasnya seseorang didukung untuk menggantikan ide tidak rasionalnya dengan yang lebih rasional untuk pemecahan masalah dalam hidup. Tujuan rational-emotive-behavior therapy adalah menghilangkan kecemasan, ketakutan, kehawatiran, ketidakyakinan diri, dan semacamnya dan mencapai prilaku rasional, kebahagiaan, dan aktualisasi diri. ${ }^{35}$

Walaupun Komaruddin Hidayat tidak menyatakan secara langsung bahwa makna hidup berhubungan dengan kesehatan mental, namun setidaknya secara tersirat ia menyatakan bahwa makna hidup mampu menjadikan kehidupan seseorang lebih baik lagi. Keringnya makna hidup yang dimiliki seseorang bisa saja berimplikasi adanya kegersangan jiwa bahkan ketakutan terhadap kematian.

Komaruddin Hidayat dalam terapinya mencoba untuk mengajak pembaca agar bijaksana dalam menghadapi kematian. Setiap manusia dihadapkan dengan suatu keadaan yang pasti akan terjadi yaitu kematian. Semua orang memang akan mengalami ketakutan terhadap kematian namun ia mengajak agar rasa ketakutan tersebut diolah untuk penyemangat diri agar menjadi individu lebih baik lagi, bukannya semakin lupa akan tujuan hidupnnya di dunia. Di sini bisa dikatakan bahwa Komaruddin Hidayat mencoba mengarahkan pembaca untuk bersikap saint, menjadikan rasa takut sebagai pemicu diri untuk lebih mendekatkan diri pada Allah dan lebih semangat dalam menjalankan kekhalifahan di muka bumi.

Yang perlu digarisbawahi dalam terapi Komaruddin Hidayat ini adalah bahwa ketakutan terhadap kematian yang dialami klien tidak harus dihilangkan seperti halnya terapi fobia, akan tetapi hanya perlu mengurangi dan mengolah rasa takut tersebut menjadi pemicu perubahan sikap yang lebih baik lagi dari sebelumnya. Menghilangkan rasa takut terhadap kematian justru

\footnotetext{
${ }^{34}$ Komaruddin Hidayat, Psikologi Kematian, h. 84-85.

${ }^{35}$ Andi Mappiare, Pengantar Konseling dan Psikoterapi, cet. 7, (Jakarta: Rajawali Pers, 2010), h. 156-157.
} 
berdampak negatif terhadap diri, bukannya perubahan tingkah laku positif diperoleh malah kemungkinan besar perubahan terjadi ke arah yang negatif.

Dalam beberapa pembahasan dalam buku Komaruddin Hidayat selalu ditegaskan bahwa setiap manusia memiliki rasa takut dan menolak kematian seperti yang disebutkan salah satunya "Secara Psikologis, jika ditelusuri lebih dalam lagi karena sesungguhnya kita semua menolak kematian”. Dari sini Penulis mengasumsikan Komaruddin Hidayat memukul secara rata dengan menyatakan setiap orang memiliki rasa takut terhadap kematian. Ada ketidaksetujuan penulis pada pernyataan ini, tidak semua orang memiliki rasa takut terhadap kematian. Kita mengenal yang namanya Sufi, seperti Rabiatul Adawiyah salah satunya yang mengidam-idamkan kematian untuk bertemu Tuhan. Namun di sini saya menyimpulkan bahwa yang dimaksudkan Komaruddin Hidayat adalah setiap orang yang lahir memang membawa rasa takut dan akan menolak kematian, namun seiring kedewasaan diri dan meningkatnya wawasan serta nilai-nilai beragama maka ketakutan tersebut akan menjadi sebuah keoptimisan.

Dan juga perlu kita ingat bahwa Komaruddin Hidayat ini hidup di tengah-tengah masyarakat urban, yang mana kehidupan mereka penuh dengan kemewahan dan memiliki keislaman yang lemah. Sepintas pernyataan Komaruddin Hidayat yang menyebutkan bahwa semua orang takut terhadap kematian dengan mengambil kesimpulan dari hal-hal yang kecil maka akan terlihat tidak begitu beralasan. Oleh karena itulah pernyataan tersebut tidak bisa diberlakukan untuk semua lapisan masyarakat, namun bisa diperuntukkan bagi masyarakat urban.

Dalam menjelaskan tentang kematian Komaruddin Hidayat lebih memaparkan peristiwa kematian dengan sangat optimis, Komaruddin Hidayat menjelaskan hal-hal indah dan tidak ada sedikit pun kengerian yang tersirat. Namun Komaruddin Hidayat juga mengingatkan, bahwa kematian yang indah ini terjadi apabila seseorang yang meninggal tersebut merupakan orang yang senang berbuat kebaikan, beriman dan bertaqwa kepada Allah swt.

Selain itu, Komaruddin Hidayat juga sering memberikan analogi untuk menjelaskan kematian, misalnya menganalogikan kematian sebagai peristiwa pulang kampung, sebuah persinggahan (dermaga), wisuda kehidupan, dan lain-lain. Cara ini memang sangat efektif karena masyarakat lebih bisa memahami pesan yang ingin disampaikan olehnya.

Seperti yang disebutkan pada pembahasan yang lalu bahwa Komaruddin Hidayat menyebutkan ada beberapa alasan mengapa seseorang takut terhadap kematian. Untuk mengubah rasa takut tersebut Komaruddin Hidayat memberikan terapi berupa pemahamanpemahaman yang benar mengenai kematian, oleh karena itulah penulis berkesimpulan bahwa terapi yang diberikan oleh Komaruddin Hidayat ini adalah rational-emotive-behavior therapy. Hal ini terbukti dengan penjelasan-penjelasan Komaruddin Hidayat untuk mengubah rasa takut yang pesimis kepada rasa takut yang optimis dengan cara mengubah pemahaman atau rasio yang berhubungan dengan kognitif orang yang memiliki rasa takut tersebut.

Komaruddin Hidayat dalam terapinya mencoba untuk mengajak pembaca agar bijaksana dalam menghadapi kematian. Setiap manusia dihadapkan dengan suatu keadaan yang pasti akan terjadi yaitu kematian. Semua orang memang akan mengalami ketakutan terhadap kematian namun ia mengajak agar rasa ketakutan tersebut diolah untuk penyemangat diri agar menjadi individu lebih baik lagi, bukannya semakin lupa akan tujuan hidupnnya di dunia. Disini bisa dikatakan bahwa Komaruddin Hidayat mencoba mengarahkan pembaca untuk bersikap saint, 
menjadikan rasa takut sebagai pemicu diri untuk lebih mendekatkan diri pada Allah dan lebih semangat dalam menjalankan kekhalifahan di muka bumi.

Yang perlu digarisbawahi dalam terapi Komaruddin Hidayat ini adalah bahwa ketakutan terhadap kematian yang dialami klien tidak harus dihilangkan seperti halnya terapi fobia, akan tetapi hanya perlu mengurangi dan mengolah rasa takut tersebut menjadi pemicu perubahan sikap yang lebih baik lagi dari sebelumnya. Menghilangkan rasa takut terhadap kematian justru berdampak negatif terhadap diri, bukannya perubahan tingkah laku positif diperoleh malah kemungkinan besar perubahan terjadi ke arah yang negatif.

\section{Penutup}

Setelah pembahasan di atas maka dapat diambil simpulan bahwa kematian merupakan sebuah kewajaran jika manusia merasa takut terhadap kematian karena manusia dilahirkan dengan rasa takut, namun hendaknya memanfaatkan rasa takut terhadap kematian ini menjadi ketakutan yang konstruktif.

Kematian begitu menakutkan karena beberapa alasan, pertama sebagian orang merasa dimanjakan oleh dunia. Kedua, manusia tidak mengetahui apa yang akan terjadi setelah mati. Ketiga, seseorang merasa banyak dosanya.

Ada empat cara yang dikemukakan Komaruddin Hidayat untuk mengatasi ketakutan terhadap kematian ini yaitu mendekatkan diri kepada Allah swt., mengetahui secara spesifik mengenai kematian, mampu lepas dari kepemilikan duniawi, dan mencari makna dalam kehidupan. Pencarian makna ini adalah memaknai kelahiran, memaknai kepemilikan, memaknai keabadian, memaknai kematian, dan memaknai panjang umur.

Dengan kematian yang pasti terjadi, maka tinggal bagaimana kita menanggapi hal tersebut apakah mempergunakan waktu yang tersisa dengan memperbanyak amal sholeh serta kebaikan terhadap sesama.

\section{DAFTAR PUSTAKA}

Aminah, Siti. "Konsep Kematian Menurut Mufassir: Studi Tentang Persiapan dan Tempat Roh Setelah Pisah dengan Badan.” Skripsi tidak diterbitkan, Fakultas Ushuluddin, IAIN Antasari, Banjarmasin, 1997.

Damm, Muhammad. Kematian, Sebuah Risalab tentang Eksistensi danKetiadaan. Depok: Kepik, 2011.

Hasan, Aliah B. Purwakania. Psikologi Perkembangan Islami: Menyingkap Rentang Kebidupan Manusia dari Prakelahiran hingga Pascakematian. Jakarta: Rajawali Pers, 2008.

Hidayat, Komaruddin. Berdamai dengan Kematian: Menjemput Ajal dengan Optimisme. Jakarta: Mizan, 2009.

Psikologi Kematian: Mengubah Ketakutan Menjadi Optimisme. Jakarta: Hikmah, 2010. 250 Wisdoms: Membuka Mata, Menangkap Makna. Jakarta: Mizan, 2010.

Jalaluddin. Psikologi Agama: Memahami Perilaku Keagamaan dengan Mengaplikasikan Prinsip-prinsip Psikologi. Jakarta: Rajawali Pers, 2010.

Mappiare, Andi. Pengantar Konseling dan Psikoterapi. Jakarta: Rajawali Pers, 2010.

Mujib, Abdul. Kepribadian dalam Psikologi Islam. Jakarta: RajaGrafindo Persada, 2007. 
Mustaqim, Abdul. Spiritualitas Kematian: Meraih Hidup Indah dan Husnul Khatimah. Yogyakarta: Kaukaba, 2011.

Mustofa, Agus. Menyelam ke Samudera Jiwa dan Ruh. Surabaya: Padma Press, 2005.

Najati, Muhammad Utsman. Jiwa dalam Pandangan Para Filosof Muslim, terj. Gazi Saloom. Bandung: Pustaka Hidayah, 2002.

Shihab, Quraish. Wawasan al-Qur'an: Tafsir Maudbu'i atas Pelbagai Persoalan Umat. B andung: Mizan, 1997. 